\title{
Low-risk MDS: non-transplant therapeutic approach
}

\author{
Moshe Mittelman \\ Tel Aviv Sourasky Medical Center; Tel Aviv University, Israel \\ Prof. Dr. Moshe Mittelman, Professor of Internal Medicine \\ and Hematology; Past Chairman, Department of Medicine, \\ Tel Aviv Sourasky Medical Center, Sackler Faculty of Medi- \\ cine, Tel Aviv University; Past President, Israel Society of \\ Hematology and Transfusion Medicine. \\ Tel Aviv Sourasky (Ichilov) Medical Center, 6 Weizmann St, \\ 64239, Israel.
}

E-mail: moshemt@gmail.com

Citation: Mittelman M. Low-risk MDS: non-transplant therapeutic approach. Cell Ther Transplant 2021; 10(2): 7-16.

\section{Summary}

A significant progress has been made over the last couple of decades in understanding the biology and treatment of myelodysplastic syndromes. Based on several parameters (\% blasts, cytogenteics, number of affected lineages) the patients are classified as having a lower-risk (LR) or higher risk disease. Here, we will focus on LR-MDS.

The patients with LR-MDS are treated with RBC transfusions as needed, with or without erythroid stimulating agents. Luspatercept, an activin analogue, is a reasonable second line agent. Among the investigational agents in this field we can mention ruxodustat (a HIF inhibitor) and imetelstat, a telomerase inhibitor. Treatment of thrombocytopenia remain challenging and an open question.

\section{Keywords}

Myelodysplastic syndrome, low-risk, diagnostics, management, targeted therapy.

\section{Introduction}

Myelodysplastic syndrome (MDS) is a clonal hematopoietic stem cell (HSC) disorder characterised by ineffective hematopoiesis accompanied by blood cytopenia and by common progression to acute myeloid leukemia (AML). MDS is mostly observed in the elderly persons [1-4]. The main clinical features of MDS are as follows:

- Clonal hematopoietic stem-cell disease(s);

- Abnormal differentiation, maturation, impaired apoptosis;

- Genetic (Immune) basis;

- Median age: 74 years;

- Incidence increases with age;

- 40-50 per 100000 in > $70 \mathrm{yr}$;

- Anemia (90\%); Pancytopenia (50\%);

- AML Transformation (20\%-60\%).

The cytomorphological examination in MDS is based on detection of bi- or tri-lineage dysplasia in different hemato- poietic lineages in the bone marrow and/or peripheral blood, and enumeration of blast cells in the samples (Fig. 1A, B).

\section{Classification}

MDS patients are classified by International Prognostic Scoring System (IPSS):

- Prognostic Parameters:

- FAB subtype: BM morphology - \% blasts;

- Cytogenetics;

- "good" vs "bad" types;

- \# Lineages affected.

- IPSS:

- Low-risk; Intermediate-1 - Lower risk disease;

- Intermediate-2; High - Higher risk disease.

- IPSS-R:

Very low; Low; Intermediate; High; Very high [5, 6]. 


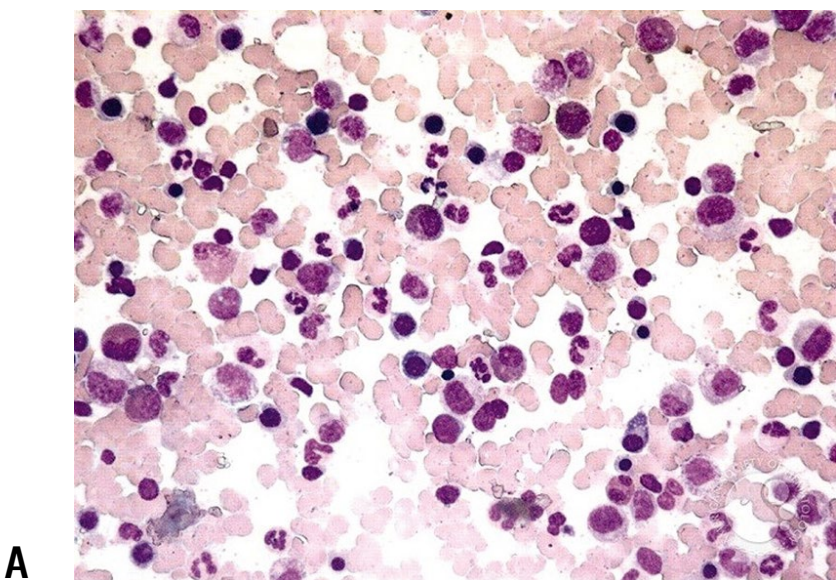

B

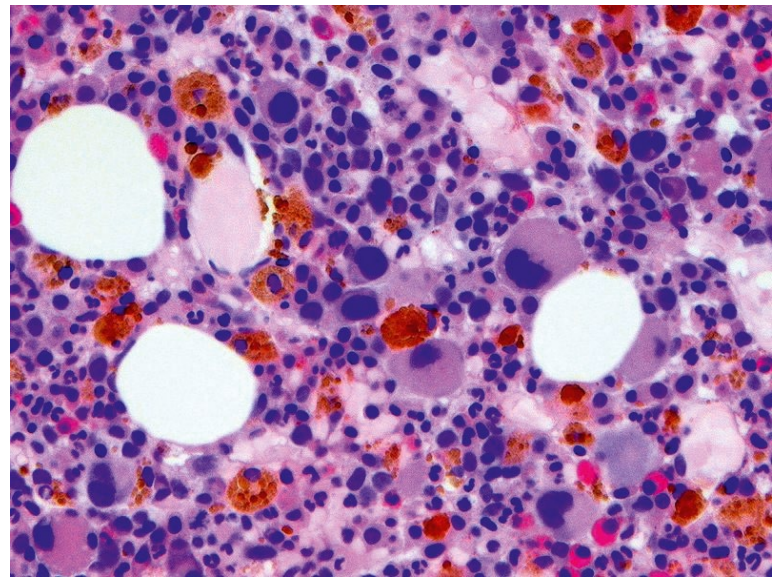

Figure 1. General pattern of bone marrow in healthy person (A) and MDS patient (B). BM of MDS patients is characterized by altered (hyper or hypo-) cellularity, numerical (hyper or hypo-) changes, morphological abnormalities in one or more hematological lineages, and potential increased $\%$ of blasts.

Evaluation of Treatment Response - Not Blac \& White:Thus, standard response criteria were proposed:

- International Working Group (IWG) 2000/2006 [5, 6]:

- Complete response (CR);

- Marrow CR (mCR); (Partial R);

- Cytogenetic response (Cyt R);

- Hematologic improvement (HI);

- Erythroid (HI-E); Neutrophil (HI-N); Platelet (HI-P).

- IWG 2018: HI-E - Erythroid response [7]:

- Transfusion burden:

- Non (0/16 wk), Low (3-7); High > 8;

- Response: minor (50\% less) or major (TI).

\section{MDS treatment}

General Strategy of MDS Treatment depends on the disease status (IPSS/R), by discerning lower-risk cases (IPSS: Low risk; Intermediate-I), and higher-risk MDS (IPSS: Intermediate-II; High risk cases).

Patient factors should be taken into account:

- Age; co-morbidities; functional status;

- Quality of life (QoL); Pt reported outcomes (PRO).

MDS treatment is often consistent with a general 'Rule of Thumb':

- Response of about 50\%;

- Response duration about 2 yr.

This is true for the following therapeutic approaches:

- RBC Transfusions;

- Erythroid stimulating agents (ESAs) ;

- Lenalidomide;

- Hypomethylating agents (HMA);

- Stem Cell Transplant (SCT).

The remaining challenges include: increasing response rate and duration of response and, finally, achieving cure of this disorder.
My experience with MDS could be traced from the Hematology-Oncology Fellowship - GW-NIH (USA) 1986-1989 at George Washington University Medical Center - Department of Hematology-Oncology (Fig. 2).

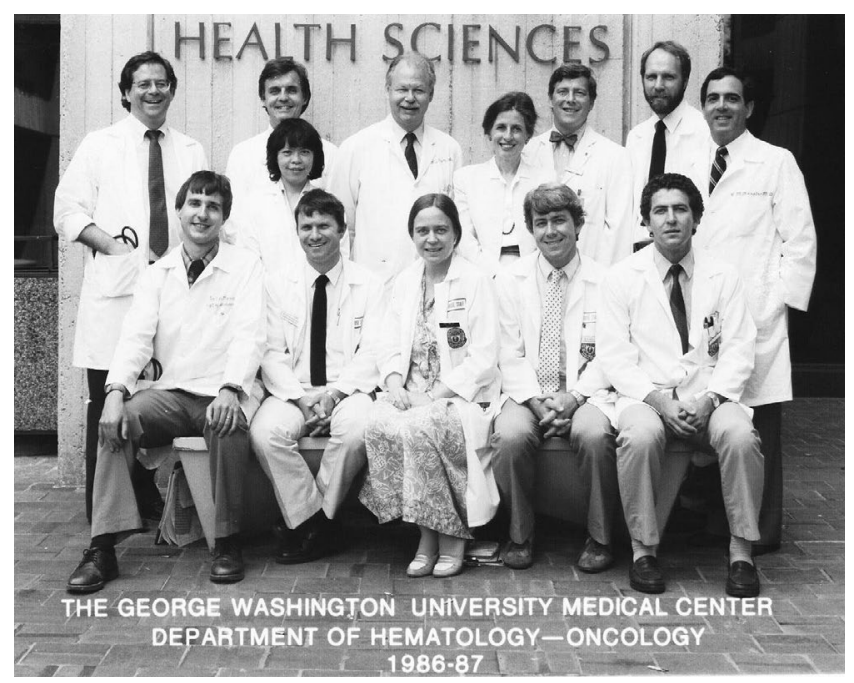

Figure 2. Hematology research team at the GeorgeWashington University (I am sitting, second on the right).

Recently, the European MDS Registry (EUMDS) is a prospective multicentre European registry for myelodysplastic syndromes (MDS), being the first international prospective, observational registry for newly diagnosed IPSS low- and intermediate- 1 risk MDS patients. 18 countries participate in EUMDS activities, i.e., Austria, Chech Republic, France, Germany, Greece, Italy, Netherlands, Romania, Spain, Sweden, UK, Denmark, Portugal, Poland, Israel, Serbia, Croatia, Switzerland.

Appropriate Guidelines were issued by EUMDS (2019) (see MDS-Europe in the net).

\section{Managing lower risk MDS}

$80 \%$ of MDS patients have a hemoglobin $<10 \mathrm{~g} / \mathrm{dl}$ at $\mathrm{di}-$ agnosis, the majority become transfusion-dependent. 
Therefore, MDS treatment for anemia still includes multiple $\mathrm{RBC}$ transfusions. Most of these patients received MDS-specific supportive care, including RBC transfusions in $50 \%$ of the cases [8].

\section{RBC Transfusions in MDS (I)}

RBC transfusions are the mostly used (50\%) in low-risk MDS. For those patients who were transfusion-independent at diagnosis, the mean interval between diagnosis and the first transfusion was 249 days [9]. For symptomatic anemia, however, limited evidence was shown.

Complications of RBC transfusions in MDS patients include the following events:

- Volume-related; TRALI (Transfusion-Related Acute Lung Injury); $\mathrm{ABO}$ incompatibility;

- RBC allo-immunization in $30 \%$ of cases [10]. Having MDS is suggested to be an independent risk factor contributing to production of RBC alloantibodies.

Iron overload due to multiple RBC transfusions is among complication of supportive therapy in MDS [11-12]. E.g., the transfusion dose density is associated with shorter progression-free survival (PFS) and worse quality of life. It showed an inverse correlation with PFS $\left(\mathrm{P}<1 \times 10^{-4}\right)$ : the dose density had an increasing effect until 3 units/16 weeks [13].

\section{RBC Transfusions in MDS (II): ELN-EUMDS 2019 Guidelines}

The questions arising:

- Hb threshold for starting the transfusions?

$-<7 \mathrm{~g} / \mathrm{dl}$ (most centers will transfuse if and when $\mathrm{Hb}$ $<7 \mathrm{~g} / \mathrm{dl})$

- Individualize (Grade B, level 1).

- Hb target levels?

- No target (Grade C, level 2) - recommendation - activate local policy.
- Transfusion frequency?

- Individualize (C-2).

- Prophylactic RBC Ag matching ? No (C-2)

- Symptomatic benefit $v s$ toxicity?

- Individualize (C-2).

For reference see [14]: Bowen D, Mittelman M, ELNEUMDS Guidelines (2019; online).

Effects of erythrocyte-stimulating agents (ESA) in low-risk MDS anemia were summarized for 2020. ESA were applied as first-line therapy (without RBC transfusions) and proved to be effective in a series of studies, as shown by $\mathrm{Hb}$ rise, fewer RBC transfused, improved QoL, with documented safety for the patients [15-19]. Hematological response was observed in a sufficient group of MDS patients (Table 1).

Therapeutic efficiency and safety of different erythrocyte-stimulating agents (ESAs) in LR-MDS was proven over 3 decades. E,g, darbopoietin A was tested in phase 3 trial ( $n=147)$, with ORR of 59\% [21]. A randomized study of Epoetin- $\alpha$ (phase 3 trial) enrolled 130 cases, with 46\% overall response rate [22]. A meta-analysis of different ESA in LR-MDS has shown an ORR of 45-73\%, and, possibly, longer overall survival of MDS patients, with $50 \%$ response [23]. Finally, a large study by EUMDS included a cohort of LR-MDS patients, at median duration of ESA therapy for 27.5 months, delayed RBC transfusions (by 6 to 23 months), lower risk of death; similar risk of progression to AML, along with safety of such treatment [24].

A team from Denmark found only marginal effects (RR 1.11.9) of ESA upon risk of venous thromboembolism (VTE) and strokes in a cohort of 2114 patients [25]. In general, the response rate to ESA in MDS was $50 \%$ at the 2 -year terms, and proven safety.

Table 1. Initial results on recombinant human Epo (rHuEP0) in MDS. The responding patients are shown in bold [20].

\begin{tabular}{|l|l|l|l|l|l|}
\hline Patient & Age / Gender & FAB & $\begin{array}{l}\text { sEP0 } \\
\mathbf{m U} / \mathbf{m L}\end{array}$ & $\begin{array}{l}\text { Hb (g/dL) } \\
\text { Week } \mathbf{0}\end{array}$ & $\begin{array}{l}\text { Hb (g/dL) } \\
\text { Week } 8\end{array}$ \\
\hline 1. ZS & $82 \mathrm{M}$ & RARS & 300 & 8.0 & 8.2 \\
\hline 2. GA & $79 \mathrm{M}$ & RARS & - & 7.8 & 8.0 \\
\hline 3. DG & $79 \mathrm{~F}$ & RARS & 550 & 7.9 & 8.0 \\
\hline 4. JL & $75 \mathrm{~F}$ & RARS & 480 & 8.1 & 7.7 \\
\hline 5. BB & $74 \mathrm{~F}$ & RARS & 660 & 8.3 & 8.0 \\
\hline 6. DA & $78 \mathrm{~F}$ & RARS & 600 & 8.1 & 8.0 \\
\hline 7. SB & $\mathbf{7 3 ~ F}$ & RA & $\mathbf{7 5}$ & $\mathbf{8 . 0}$ & 11.0 \\
\hline 8. GK & $68 \mathrm{~F}$ & RARS & - & 8.2 & 8.3 \\
\hline 9. SY & $65 \mathrm{M}$ & RARS & - & 7.8 & 8.1 \\
\hline 10. SM & $59 \mathrm{~F}$ & RA & $\mathbf{4 7 1}$ & $\mathbf{8 . 9}$ & $\mathbf{9 . 4}$ \\
\hline 11. AF & $80 \mathrm{M}$ & RA & 500 & 7.3 & 6.9 \\
\hline 12. MBB & $68 \mathrm{~F}$ & CMML & 400 & 8.0 & 7.8 \\
\hline 13. IS & $\mathbf{8 2 ~ F ~}$ & RA & $\mathbf{9 6}$ & $\mathbf{7 . 4}$ & 11.9 \\
\hline
\end{tabular}




\section{EP0 non-erythroid (immunologic) effects}

Therapeutic efficiency of rhEPO was documented in myeloma-associated anemia [26]. Moreover, probable anti-neoplastic effects of erythropoietin were shown in experimental murine myeloma $[27,28]$.

Other events associated with erythropoietin therapy in patients with hematological disorders include a decreased glucose level [29], probable bone loss by targeting monocytes and osteoclastic activity in murine model [30], as well as decrease in serum IL-6 upon the EPO therapy [31], as seen in Fig. 3. In myelodysplastic syndrome, improvement of $\mathrm{T}$ cell immune functions was an additional positive effect observed after erythropoietin treatment [32].

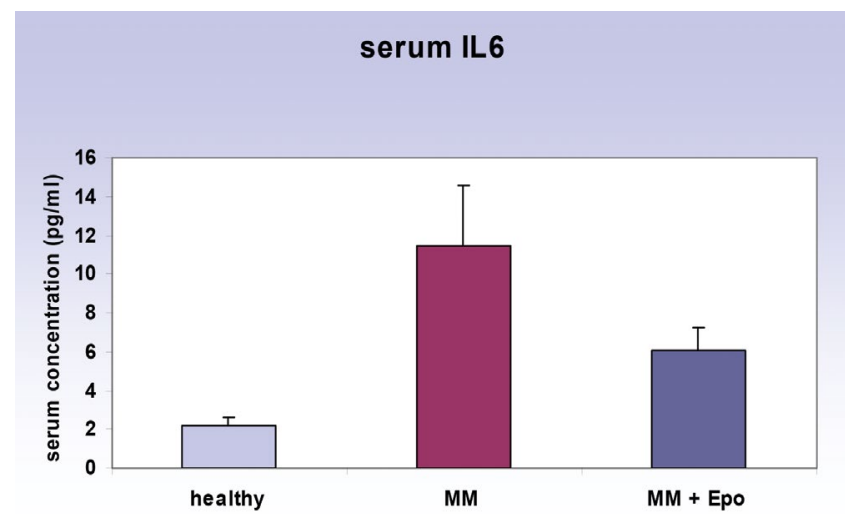

Figure 3. Comparative IL-6 levels in blood serum of heathy persons, in MM patients, and in Epo-treated MM patients [31]

ESA treatment may fail in sufficient part of MDS patients. Clinical outcomes in LR-MDS in the non-responsive cohort were studied by Park et al. [33].

The study represented a retrospective analysis of LR-MDS patients without $5 \mathrm{q}$ chromosome deletion. Of them, $653 \mathrm{ex}-$ perienced primary failure and 494 experienced relapse after a response. Median OS among ESA non-responders was 4.2 years in relapsing patients versus 3.7 years in primary failure. Second-line treatment was performed in 39\% of them. Hypomethylating agents (HMA) were used in 336 patients, with $46 \%$ response, and lenalidomide, in 88 patients with $39 \%$ response rates. However, the five-year OS for patients receiving HMA, lenalidomide, or other therapies was $36.5 \%$, $41.7 \%$, and $51 \%$, respectively ( $\mathrm{P}=.21)$. In a multivariable analysis, there was no significant OS difference among the three groups. Yes, we need to do better...

\section{Lenalidomide therapy}

Several studies demonstrated efficiency of Lenalidomide in LR-MDS, either with or without $5 q$ deletion. List et al. [34] have shown that transfusion demands were reduced in $76 \%$ of the treated patients with $5 \mathrm{q}$ chromosome deletion, and some of them did not longer require transfusions, regardless of the karyotype complexity. The response to lenalidomide occurred at the median time of 4.6 weeks and retained for a median of 2 years. In the meta-analysis by Lian et al. [35], overall rate of hematological erythrocyte response was 58\%. The patients with $5 q$ deletion had significantly higher rate of response, significantly prolonged overall survival and lower risk of AML progression. The drug showed a predictable and manageable safety profile in LR-MDS in terms of adverse effects [36]. P53 mutations with higher TP53 protein expression in $\mathrm{BM}$ progenitors of lenalidomide-treated patients proved to be associated with higher AML risk and shorter OS [37-39].

Below are main results of the MDS-004 study in Del (5q) MDS patients [38]:

- RRBC TI 56\%; Cytogenetic response was observed in $50 \%$ at $10 \mathrm{mg}$ of Len daily

- Adverse effects: cytopenia, rash, gastrointestinal, thrombosis

- No effect on leukemic transformation

- Results with non-del (5q) patients: MDS-005 [39]

- Among a group of 239 pts (lenalidomide or placebo), transfusion independence was achieved in $27 \%$ ( $v s$ 2.5\% with placebo) at 8 weeks of Len therapy.

\section{Other therapeutic targets}

\section{TGF-binding drugs}

Hence, anemia remains a sufficient problem in some LR-MDS patients. What can we offer when ESA, or Lenalidomide treatment fail? Newer drugs, e.g., activin analogues, may potentially improve erythropoiesis, by TGF-b binding, or Smad2/3 inhibition. E.g., Luspatercept was tested in a PACE-MDS Trial (ACE-536) at the Phase II, (s/c injections, every 3 wk; 58 pts; post ESA), as reported by Platzbecker et al. [40]. The drug caused a significant dose-dependent increase in blood $\mathrm{Hb}$ contents, and, after 4-mo treatment at a dose of $0.75-1.75 \mathrm{mg} / \mathrm{kg}$, reduced demands for RBC transfusions.

The MEDALIST study was a phase 3, randomized, doubleblind, placebo-controlled trial with transfusion-dependent MDS. Luspatercept therapy led to RBC transfusion independence in lower-risk MDS patients resistant to ESA [41]. Of the 229 patients, 153 were randomly assigned to receive luspatercept or placebo, s/c every 3 weeks, for $\geq 24$ weeks. Transfusion independence for 8 weeks or longer was observed in $38 \%$ of the patients in Luspatercept group versus $13 \%$ in the placebo group $(\mathrm{P}<0.001)$.

Sotatercept (ACE-011), a drug with similar action, was recently subject to phase 2 study carried out by Komrokji et al. [42]. 74 patients enrolled were ineligible for, or refractory to ESA therapy. Clinical response was documented in $40-50 \%$ (better outcomes in those with lower transfusion burden). Adverse effects manifested as diarrhea, bone pain, fatigue, GI, edema, lipase increase.

A special COMMANDS Trial aimed to compare Luspatercept versus erythropoietin is launched now [43].

\section{Low Dose/Oral hypomethylating agents (HMA) in LR-MDS}

A prospective trial (Phase 2) was performed using Azacitidine versus best supportive care (BSC). The primary endpoint was erythroid hematologic improvement which was achieved in $44.4 \%$ of cases after 9 treatment rounds, versus $5.5 \%$ of patients treated with BSC, as well as transfusion independence in all the drug responders for a median of 1 year [44]. 
Low-dose decitabine versus low-dose azacitidine (Aza) were applied in the phase II study [45]. A total of 113 patients were treated: 35\% with Aza and 65\% with Dec. The ORRs were $70 \%$ and $49 \%$ for Dec and Aza, respectively. Transfusion independence was achieved in $32 \%$ of decitabine-treated patients, and the treatment was well tolerated.

A meta-analysis performed by Komrokji et al. (2018) [46] concerning efficiency of Aza in a total sample of 233 patients with, mostly, non-del(5q) LR-MDS has shown that the RBC transfusion independence was achieved in $39 \%$ of the cases, at $\geq 6$ azacitidine treatment cycles.

Several years ago, a report on clinical effects of peroral Aza (cc-486) in LR-MDS was published [47]. The study included 216 MDS patients. The disease status was assessed after cycle 6. The ORR was $40 \%$, including hematologic improvement in $28 \%$ of patients, and transfusion independence lasted for 56 days in $47 \%$ of initially transfusion-dependent cases.

Therefore, QUAZAR study (AZA-MDS-003) was continued as randomized controlled trial (RCT), Phase 3, in LR-MDS patients with anemia and thrombocytopenia [48]. The patients received CC- 486 or placebo. $31 \%$ and $11 \%$ of patients, respectively, achieved RBC-TI in the main and placebo group, which lasted, for, respectively, 11.1 and 5.0 months. Platelet improvement rate was also higher in the CC-486 $\operatorname{arm}(24.3 \%$ vs $6.5 \%)$.

\section{Roxadustat (FG-4592)}

Usage of oral prolyl hydroxylase (PH) inhibitors may be a promising tool of anemia treatment, since the $\mathrm{PH}$ inhibition may stabilize hypoxia-inducible factor (HIF). This factor induces erythropoietin production and decreases hepcidin, thus promoting iron mobilization [49]. Recently, this drug was shown to be safe and efficient in the patients with anemia caused by chronic renal failure - CRF [50].

Roxadustat is another $\mathrm{PH}$ inhibitor(Fibrogen) undergoes a clinical FGCL-4592-082 trial which is an open label study including 24 pts, achieving 38\% TI if used at a dose of $2.5 \mathrm{mg} / \mathrm{kg}, \times 3 / \mathrm{wk}$ [51]. Now this drug is under phase 3 , randomized controlled trial, with 156 patients.

\section{Telomerase inhibitors}

Clinical trials with Imetelstat, a telomerase inhibitor, were performed in the patients with LR-MDS anemia [52-54]. Phase 2 trial is an open, single arm study, with the drug dose of $7.5 \mathrm{mg} / \mathrm{kg} \mathrm{I} / \mathrm{V} \mathrm{q} 4 \mathrm{wk}$. A subgroup of 38 LR-MDS patients were selected with transfusion dependence, ESA relapse/ resistance, non-del(5q), being hypomethylating agent and lenalidomide naïve. Of them, 16 patients (42\%) achieved transfusion independence. This effect was durable (a median of $21 \mathrm{mo}$ ) and accompanied by reduced telomerase activit. Phase 3 (a placebo-controlled study) is ongoing.

\section{Treatment of thrombocytopenia in MDS}

Platelet transfusions (PLT) are made in MDS patients. However, there is no evidence on their efficiency. This procedure is indicated in cases of active bleeding and should be performed per local guidelines $[14,55]$. In absence of active bleeding, the platelet transfusion cannot be routinely recommended!. One may consider "thrombostatics", e.g., Tranexamic acid, or Anti-fibrinolytic solutions, (Hexakapron).

\section{Romiplostim in MDS}

For the last decade, several groups study safety and efficacy of romiplostim, a synthetic protein, an analogue of thrombopoietin which increases platelet production, for treatment of MDS patients with thrombocytopenia. The phase I/II study by Kantarjan et al. [56] in 44 patients have shown a durable platelet response in $46 \%$ cases. After achieving platelet response ( 4 weeks) the patients were treated with romiplostim for up to 1 year. Serious adverse effects were registered in $11 \%$ of the cases, and 2 patients progressed to AML.

The Phase II study was arranged as a randomized, placebocontrolled trial which included a total of 250 LR-MDS patients randomized $2: 1$, to receive romiplostim or placebo weekly for 58 weeks [57]. The incidence of bleeding events was reduced in the romiplostim group, and platelet response rates proved to be higher in the patients who received romiplostim. However, study drug was stopped because of excess blasts and potential AML risk following this treatment. Later on, upon 5-year of this cohort, the percentages of patients with AML (12\%) in romiplostim group were similar (11\%) to those in placebo group, as shown by Kantarjian et al. [58]. In a special commentary, I emphasized that these long-term results were indeed reassuring, however, one has to bear in mind that treatment had been discontinued [59]. Thus, the long-term data reflect the outcome of a long-term follow up, while the drug exposure was relatively short.

\section{Eltrombopag in MDS}

Eltrombopag is an agonist of thrombopoietin receptor which promotes growth and differentiation of megakaryocytes. Since 2014, it was approved by FDA for treatment of aplastic anemia, stimulating production of platelets, RBC and leukocytes. In LR-MDS patients with thrombocytopenia, it has shown efficiency of $47 \%$ in terms of platelet responses, versus $3 \%$ in the placebo group (Oliva et al., 2017) [60].

The ASPIRE study (Part I) was an open-label, double-blind study of patients with advanced MDS treated for 8 weeks with Eltrombopag, and randomised at later terms [61]. Four patients of 17 achieved increased platelet counts following treatment, and ten had reduced platelet transfusion requirements. Serious adverse events were reported in $58 \%$ of eltrombopag-treated, and in $68 \%$ placebo-treated patients. In ASPIRE II, fewer adverse events were registered.

Combined effects of Eltrombopag and Azacytidin (AZA) were addressed in the SUPPORT Study [62]. The intermediate-1, intermediate-2, or high-risk MDS patients with low platelet counts were randomized 1:1 to eltrombopag, or placebo, plus azacitidine. The development of this study was, however, stopped due to efficacy outcomes, and for safety problems.

The French MDS group (GFM) have recently presented their experience using long-term eltrombopag, with encouraging clinical efficacy. These promising data might assist in lifting the embargo on thrombomimetic agnets [63].

\section{Immunosuppressive therapy}

Despite broad arsenal of novel therapeutic agents for MDS therapy, there are many LR-MDS patients with anemia who 
are resistant or have lost their response to such drugs. Therefore, immunosuppressive treatment (IST) in these cases is well justified, on the basis of similarity between severe aplastic anemia and hypoplastic MDS. Some experience in this field exists with ATG and/or cyclosporine treatment [64]. Clinical response, however, is dependent on the MDS patient's age, transfusion history, and karyotype pattern, with erythroid response rate of $25-40 \%$.

A large study published by Stahl et al. reported results of IST results obtained for cohort from 15 centers in Europe and USA, including 207 pts with MDS receiving IST [65].

The most common IST regimen was anti-thymocyte globulin (ATG) plus prednisone (43\%). The overall response rate ORR $48.8 \%$, with $11 \%$ reaching complete remission, and transfusion independence (RBC-TI) in 30\% of the cases. Median overall survival (OS) was $47.4 \mathrm{mo}$, being longer for the patients with transfusion independence. The RBC-TI was associated with a bone marrow hypocellularity $(<20 \%)$. Age, HLA-DR15 positivity did not predict clinical response to IST.

\section{Iron Overload}

Iron deposition in the patients occurs due to intrinsic mechanisms of MDS, and as a result of multiple RBC transfusion, causing damage of liver and other organs.

Iron chelator therapy is effective in these cases. A retrospective study based on the European MDS Registry data was recently published by Hoeks et al. [66]. The results of chelator treatment in MDS were compared with non-chelated patients. The propensity-score analysis has revealed improved OS for chelated patients, with erythroid response in up to $39 \%$ of the treated cohort. A similar TELESTO study (the only prospective) included 225 patients with high serum ferritin levels after multiple RBC transfusions treated with Deferasirox [67]. Following continuous treatment (0.5 to 3 years), median EFS was prolonged by ca. 1 year (1440 d vs $1091 \mathrm{~d}$ ) with deferasirox $v s$ placebo, at $36 \%$ reduction of events.

Several eligibility criteria are proposed for initiating the chelator therapy $[14,68]$ (Mittelman et al., 2008, current Guidelines 2019; MDS-EUROPE online [14]: 1. Patients classified as low or Int 1, according to the International Prognostic Scoring System; 2. Patients with serum ferritin levels $>1000 \mu \mathrm{g} / \mathrm{Ll}$ and those who received a total of 20-25 RBC units; 3. Patients whose blood transfusion requirement has increased significantly; 4. Patients with sufficient organ damage.

\section{Summary and future prospects}

Current treatment of the low-risk MDS includes the following:

- ESA +/- RBC transfusions;

- Lenalidomide (del 5q);

- $2^{\text {nd }}$ Line:

- Luspatercept; Roxadustat; Imetelstat; HMA (?)
Future prospectives:

- Combinations: ESA + other hematopoiesis-stimulating drugs;

- Novel agents;

- Low platelet counts in MDS patients:

- Therapeutic approaches are still challenging.

\section{Conflict of interest}

Disclosures: Research funding: Celgene; Johnson \& Johnson; Roche; Novartis; Gilead. Speakers' bureau: Celgene; Johnson \& Johnson; Novartis. Advisory boards (non-paid): Pfizer; Amgen; Roche; Novartis.

\section{References}

1. Mittelman M. The myelodysplastic syndromes--1990. Isr J Med Sci. 1990;26(8):468-478. PMID: 2205597

2. Malcovati L, Hellström-Lindberg E, Bowen D, Adès L, Cermak J, Del Cañizo C, Della Porta MG, Fenaux P, Gattermann N, Germing U, et al.; European Leukemia Net. Diagnosis and treatment of primary myelodysplastic syndromes in adults: recommendations from the European LeukemiaNet. Blood. 2013;122(17):2943-2964. doi: 10.1182/ blood-2013-03-492884

3. Adès L, Itzykson R, Fenaux P. Myelodysplastic syndromes. Lancet. 2014; 383(9936):2239-2252. doi: 10.1016/ S0140-6736(13)61901-7

4. Rollison DE, Howlader N, Smith MT, Strom SS, Merritt WD, Ries LA, Edwards BK, List AF. Epidemiology of myelodysplastic syndromes and chronic myeloproliferative disorders in the United States, 2001-2004, using data from the NAACCR and SEER programs. Blood. 2008; 112(1):45-52. doi: 10.1182/blood-2008-01-134858

5. Cheson BD, Bennett JM, Kantarjian H, Pinto A, Schiffer CA, Nimer SD, Löwenberg B, Beran M, de Witte TM, Stone $\mathrm{RM}$, et al. ; WHO International working group. Report of an international working group to standardize response criteria for myelodysplastic syndromes. Blood. 2000; 96(12):36713674. PMID: 11090046

6. Cheson BD, Greenberg PL, Bennett JM, Lowenberg B, Wijermans PW, Nimer SD, Pinto A, Beran M, de Witte TM, Stone RM, et al. Clinical application and proposal for modification of the International Working Group (IWG) response criteria in myelodysplasia. Blood. 2006; 108(2):419-425. doi: 10.1182/blood-2005-10-4149

7. Platzbecker U, Fenaux P, Adès L, Giagounidis A, Santini V, van de Loosdrecht AA, Bowen D, de Witte T, Garcia-Manero G, Hellström-Lindberg E, et al. Proposals for revised IWG 2018 hematological response criteria in patients with MDS included in clinical trials. Blood. 2019; 133(10):1020-1030. doi: 10.1182/blood-2018-06-857102

8. Schanz J, Tüchler H, Solé F, Mallo M, Luno E, Cervera J, Granada I, Hildebrandt B, Slovak M, Ohyashiki K, et al. New comprehensive cytogenetic scoring system for primary myelodysplastic syndromes (MDS) and oligoblastic 
acute myeloid leukemia after MDS derived from an International Database Merge. J Clin Oncol. 2012; 30(8):820-829. doi: 10.1200//CO.2011.35.6394

9. de Swart L, Smith A, Johnston TW, , Haase B, Droste J, Fenaux P, Symeonidis A, Sanz G, Hellström-Lindberg E, Čermák J, et al. Validation of the revised International Prognostic Scoring System (IPSS-R) in patients with lower-risk myelodysplastic syndromes: a report from the prospective European LeukaemiaNet MDS (EUMDS) registry. Br J Hematol. 2015;170:372-383. doi: 10.1111/bjh.13450

10. Rozovski U, Ben-Tal O, Kirgner I, Mittelman M, Hareuveni $M$. Increased incidence of red blood cell alloantibodies in myelodysplastic syndrome. Isr Med Assoc J. 2015; 17(10): 624-627. PMID: 26665317

11. Steensma DP, Heptinstall KV, Johnson VM, Novotny PJ, Sloan JA, Camoriano JK, Niblack J, Bennett JM, Mesa RA. Common troublesome symptoms and their impact on quality of life in patients with myelodysplastic syndromes (MDS): results of a large internet-based survey. Leuk Res. 2008; 32(5):691-698. doi: 10.1016/j.leukres.2007.10.015

12. Platzbecker U, Fenaux P, Adès L, Giagounidis A, Santini V, van de Loosdrecht AA, Bowen D, de Witte T, Garcia-Manero G, Hellström-Lindberg E, et al. Proposals for revised IWG 2018 hematological response criteria in patients with MDS included in clinical trials. Blood. 2019;133(10):1020-1030. doi: 10.1182/blood-2018-06-857102

13. de Swart L, Crouch S, Hoeks M, Smith A, Langemeijer S, Fenaux P, Symeonidis A, Cermâk J, Hellström-Lindberg E, Stauder R, et al. Impact of red blood cell transfusion dose density on progression-free survival in patients with lower-risk myelodysplastic syndromes. Haematologica. 2020; 105:632-639. doi: 10.3324/haematol.2018.212217

14. Bowen D, Mittelman M, et al. ELN-EUMDS Guidelines (2019). https://mds-europe.org/

15. Mittelman M. Recombinant erythropoietin in myelodysplastic syndromes: whom to treat and how? More questions than answers. Acta Haematol. 1993;90(2):53-57. doi: $10.1159 / 000204376$

16. Mittelman M, Lessin LS. Clinical application of recombinant erythropoietin in myelodysplasia. Hematol Oncol Clin North Am. 1994; 8(5):993-1009. PMID: 7852220

17. Hellström-Lindberg E, Negrin R, Stein R, Krantz S, Lindberg G, Vardiman J, Ost A, Greenberg P. Erythroid response to treatment with G-CSF plus erythropoietin for the anaemia of patients with myelodysplastic syndromes: proposal for a predictive model. Br J Haematol. 1997; 99(2):344-351. doi: 10.1046/j.1365-2141.1997.4013211.x

18. Cazzola M, Beguin Y, Kloczko J, Spicka I, Coiffier B. Once-weekly epoetin beta is highly effective in treating anaemic patients with lymphoproliferative malignancy and defective endogenous erythropoietin production. Br J Haematol. 2003;122(3):386-393. doi: 10.1046/j.1365-2141.2003

19. Gafter-Gvili A, Rozen-Zvi B, Vidal L, Leibovici L, Vansteenkiste J, Gafter U, Shpilberg O. Intravenous iron supplementation for the treatment of chemotherapy-induced anaemia - systematic review and meta-analysis of randomised controlled trials. Acta Oncol. 2013; 52(1):18-29. doi: 10.3109/0284186X.2012.702921

20. Mittelman M, Floru S, Djaldetti M. Subcutaneous erythropoietin for treatment of refractory anemia in hematologic disorders. Blood. 1992; 80(3):841-843. PMID: 1638033

21. Platzbecker U, Symeonidis A, Oliva EN, Goede JS, Delforge M, Mayer J, Slama B, Badre S, Gasal E, Mehta B, Franklin J. A phase 3 randomized placebo-controlled trial of darbepoetin alfa in patients with anemia and lower-risk myelodysplastic syndromes. Leukemia. 2017; 31(9):1944-1950. doi: 10.1038/leu.2017.192

22. Fenaux P, Santini V, Spiriti MAA, Giagounidis A, Schlag R, Radinoff A, Gercheva-Kyuchukova L, Anagnostopoulos A, Oliva EN, Symeonidis A, et al. A phase 3 randomized, placebo-controlled study assessing the efficacy and safety of epoetin- $\alpha$ in anemic patients with low-risk MDS. Leukemia. 2018; 32(12):2648-2658. doi: 10.1038/s41375-018-0118-9

23. Park S, Greenberg P, Yucel A, Farmer C, O'Neill F, De Oliveira Brandao C, Fenaux P. Clinical effectiveness and safety of erythropoietin-stimulating agents for the treatment of low- and intermediate-1-risk myelodysplastic syndrome: a systematic literature review. Br J Haematol. 2019; 184(2):134-160. doi: 10.1111/bjh.15707

24. Garelius HK, Johnston WT, Smith AG, Park S, de Swart L, Fenaux P, Symeonidis A, Sanz G, Čermák J, Stauder R, et al. Erythropoiesis-stimulating agents significantly delay the onset of a regular transfusion need in nontransfused patients with lower-risk myelodysplastic syndrome. J Intern Med. 2017; 281(3):284-299. doi: 10.1111/joim.12579

25. Horváth-Puhó E, Suttorp MM, Frederiksen H, Hoekstra T, Dekkers OM, Pedersen L, Cannegieter SC, Dekker FW, Sørensen HT. Erythropoiesis-stimulating agents and cardiovascular events in patients with myelodysplastic syndrome and multiple myeloma. Clin Epidemiol. 2018; 10:1371-1380. doi: 10.2147/CLEP.S172306

26. Mittelman M, Zeidman A, Fradin Z, Magazanik A, Lewinski UH, Cohen A. Recombinant human erythropoietin in the treatment of multiple myeloma-associated anemia. Acta Haematol. 1997; 98(4):204-10. doi: 10.1159/000203625

27. Mittelman M, Neumann D, Peled A, Kanter P, Haran-Ghera N. Erythropoietin induces tumor regression and antitumor immune responses in murine myeloma models. Proc Natl Acad Sci U S A. 2001; 98(9):5181-5186. doi: $10.1073 /$ pnas.081275298

28. Mittelman M, Zeidman A, Kanter P, Katz O, Oster H, Rund D, Neumann D. Erythropoietin has an anti-myeloma effect - a hypothesis based on a clinical observation supported by animal studies. Eur J Haematol. 2004; 72(3):155-165. doi: 10.1046/j.0902-4441.2003.00190.x

29. Oster HS, Gvili Perelman M, Kolomansky A, Neumann D, Mittelman M. Erythropoietin treatment is associated with decreased blood glucose levels in hematologic patients. Acta Haematol. 2021; 144(3):252-258. doi: 10.1159/000507974

30. Hiram-Bab S, Liron T, Deshet-Unger N, Mittelman M, Gassmann M, Rauner M, Franke K, Wielockx B, Neumann D, 
Gabet Y. Erythropoietin directly stimulates osteoclast precursors and induces bone loss. FASEB J. 2015; 29(5):18901900. doi: $10.1096 /$ f. $14-259085$

31. Prutchi-Sagiv S, Golishevsky N, Oster HS, Katz O, Cohen A, Naparstek E, Neumann D, Mittelman M. Erythropoietin treatment in advanced multiple myeloma is associated with improved immunological functions: could it be beneficial in early disease? Br J Haematol. 2006; 135(5):660-672. doi: $10.1111 / \mathrm{j} .1365-2141.2006 .06366 . \mathrm{x}$

32. Deshet-Unger N, Oster HS, Prutchi-Sagiv S, Maaravi N, Golishevski N, Neumann D, Mittelman M. Erythropoietin administration is associated with improved T-cell properties in patients with myelodysplastic syndromes. Leuk Res. 2017; 52:20-27. doi: 10.1016/j.leukres.2016.11.002

33. Park S, Hamel JF, Toma A, Kelaidi C, Thépot S, Campelo MD, Santini V, Sekeres MA, Balleari E, Kaivers J, et al. Outcome of lower-risk patients with myelodysplastic syndromes without $5 \mathrm{q}$ deletion after failure of erythropoiesis-stimulating agents. J Clin Oncol. 2017; 35(14):1591-1597. doi: 10.1200/JCO.2016.71.3271

34. List A, Dewald G, Bennett J, Giagounidis A, Raza A, Feldman E, Powell B, Greenberg P, Thomas D, Stone R, et al. Lenalidomide in the myelodysplastic syndrome with chromosome 5q deletion. N Engl J Med. 2006; 355(14):14561465. doi: 10.1056/NEJMoa061292

35. Lian XY, Zhang ZH, Deng ZQ, He PF, Yao DM, Xu ZJ, Wen XM, Yang L, Lin J, Qian J. Efficacy and safety of lenalidomide for treatment of low-/intermediate-1-risk myelodysplastic syndromes with or without $5 q$ deletion: a systematic review and meta-analysis. PLoS One. 2016; 11(11):e0165948. doi: 10.1371/journal.pone.0165948

36. Almeida A, Fenaux P, Garcia-Manero G, Goldberg SL, Gröpper S, Jonasova A, Vey N, Castaneda C, Zhong J, Beach CL, Santini V. Safety profile of lenalidomide in patients with lower-risk myelodysplastic syndromes without $\operatorname{del}(5 \mathrm{q})$ : results of a phase 3 trial. Leuk Lymphoma. 2018; 59(9):21352143. doi: $10.1080 / 10428194.2017 .1421758$

37. Saft L, Karimi M, Ghaderi M, Matolcsy A, Mufti GJ, Kulasekararaj A, Göhring G, Giagounidis A, Selleslag D, Muus P. p53 protein expression independently predicts outcome in patients with lower-risk myelodysplastic syndromes with del(5q). Haematologica. 2014; 99(6):1041-1049. doi: $10.3324 /$ haematol.2013.098103

38. Fenaux P, Giagounidis A, Selleslag D, Beyne-Rauzy O, Mufti G, Mittelman M, Muus P, Te Boekhorst P, Sanz G, Del Cañizo $\mathrm{C}$, et al. A randomized phase 3 study of lenalidomide versus placebo in $\mathrm{RBC}$ transfusion-dependent patients with low-/Intermediate-1-risk myelodysplastic syndromes with del5q. Blood. 2011; 118(14):3765-3776. doi: 10.1182/ blood-2011-01-330126

39. Santini V, Almeida A, Giagounidis A, Gröpper S, Jonasova A, Vey N, Mufti GJ, Buckstein R, Mittelman M, Platzbecker U, et al. Randomized phase III study of lenalidomide versus placebo in RBC transfusion-dependent patients with lower-risk non-del(5q) myelodysplastic syndromes and ineligible for or refractory to erythropoiesis-stimulating agents. J Clin Oncol. 2016;34(25):2988-2996. doi: 10.1200/ LCO.2015.66.0118
40. Platzbecker U, Germing U, Götze KS, Kiewe P, Mayer K, Chromik J, Radsak M, Wolff T, Zhang X, Laadem A, Sherman ML, Attie KM, Giagounidis A. Luspatercept for the treatment of anaemia in patients with lower-risk myelodysplastic syndromes (PACE-MDS): a multicentre, open-label phase 2 dose-finding study with long-term extension study. Lancet Oncol. 2017; 18(10):1338-1347. doi: 10.1016/S14702045(17)30615-0

41. Fenaux P, Kiladjian JJ, Platzbecker U. Luspatercept for the treatment of anemia in myelodysplastic syndromes and primary myelofibrosis. Blood. 2019; 133(8):790-794. doi: $\underline{10.1182 / \text { blood-2018-11-876888 }}$

42. Komrokji R, Garcia-Manero G, Ades L, Prebet T, Steensma DP, Jurcic JG, Sekeres MA, Berdeja J, Savona MR, Beyne-Rauzy O, et al. Sotatercept with long-term extension for the treatment of anaemia in patients with lower-risk myelodysplastic syndromes: a phase 2, dose-ranging trial. Lancet Haematol. 2018; 5(2):e63-e72. doi: 10.1016/S2352$\underline{3026(18) 30002-4}$

43. Fenaux P, Platzbecker U, Mufti GJ, Garcia-Manero G, Buckstein R, Santini V, Díez-Campelo M, Finelli C, M Cazzola, et al. Luspatercept in patients with lower-risk myelodysplastic syndromes. New Engl J Med. 2020; 382:140-151. doi: 10.1056/NEJMoa1908892

44. Sanchez-Garcia J, Falantes J, Medina Perez A, Hernandez-Mohedo F, Hermosin L, Torres-Sabariego A, Bailen A, Hernandez-Sanchez JM, Solé Rodriguez M, Casaño FJ, et al. Prospective randomized trial of 5 days azacitidine versus supportive care in patients with lower-risk myelodysplastic syndromes without $5 \mathrm{q}$ deletion and transfusion-dependent anemia. Leuk Lymphoma. 2018;59(5):1095-1104. doi: $10.1080 / 10428194.2017 .1366998$

45. Jabbour E, Short NJ, Montalban-Bravo G, Huang X, Bueso-Ramos C, Qiao W, Yang H, Zhao C, Kadia T, Borthakur G, et al. Randomized phase 2 study of low-dose decitabine vs low-dose azacitidine in lower-risk MDS and MDS/MPN. Blood. 2017;130(13):1514-1522. doi: 10.1182/ blood-2017-06-788497

46. Komrokji R, Swern AS, Grinblatt D, Lyons RM, Tobiasson M, Silverman LR, Sayar H, Vij R, Fliss A, Tu N, Sugrue MM. Azacitidine in lower-risk myelodysplastic syndromes: A meta-analysis of data from prospective studies. Oncologist. 2018; 23(2):159-170. doi: 10.1634/theoncologist.2017-0215

47. Garcia-Manero G, Almeida A, Giagounidis A, Platzbecker U, Garcia R, Voso MT, Larsen SR, Valcarcel D, Silverman LR, Skikne B, Santini V. Design and rationale of the QUAZAR Lower-Risk MDS (AZA-MDS-003) trial: a randomized phase 3 study of CC-486 (oral azacitidine) plus best supportive care vs placebo plus best supportive care in patients with IPSS lower-risk myelodysplastic syndromes and poor prognosis due to red blood cell transfusion-dependent anemia and thrombocytopenia. BMC Hematol. 2016;16:12. doi: $10.1186 / \mathrm{s} 12878-016-0049-5$

48. Garcia-Manero G, Santini V, Almeida A, Platzbecker U, Jonasova A, Silverman LR, Falantes J, Reda G, Buccisano F, Fenaux P et al. Phase III, Randomized, placebo-controlled trial of CC-486 (oral azacitidine) in patients with 
lower-risk myelodysplastic syndromes. J Clin Oncol. 2021: JCO2002619. doi: 10.1200/JCO.20.02619

49. Joharapurkar AA, Pandya VB, Patel VJ, Desai RC, Jain MR. Prolyl hydroxylase inhibitors: a breakthrough in the therapy of anemia associated with chronic diseases. J Med. Chem. 2018, 61 (16): 6964-6982. doi: 10.1021/acs.jmedchem.7b01686

50. Del Vecchio L, Locatelli F. Roxadustat in the treatment of anaemia in chronic kidney disease. Expert Opin Investig Drugs. 2018; 27(1):125-133. doi: 10.1080/ $\underline{13543784.2018 .1417386}$

51. Henry DH; Glaspy J, Harrup RA, Mittelman M, Zhou A, Carraway HE, Bradley C, Saha G, Bartels P, Leong R, et al. Oral Roxadustat demonstrates efficacy in anemia secondary to lower-risk myelodysplastic syndrome irrespective of ring sideroblasts and baseline erythropoietin levels. Blood. 2020,136, 29-30. ASH Meeting Abstract \#1277, Dec 5, 2020.

52. Fenaux $\mathrm{P}$ et al. Imetelstat provides durable transfusion independence in heavily transfused non-del(5q) LR-MDS R/R to ESAS. EHA 2019.

53. Platzbecker U, Fenaux P, Steensma DP, Van Eygen K, Raza A, Germing U, Font P, Diez-Campelo M, Thepot S, Vellenga $\mathrm{E}$, et al. Treatment with Imetelstat provides durable transfusion independence (TI) in heavily transfused non-del(5q) lower risk MDS (LR-MDS) relapsed/refractory (R/R) to erythropoiesis stimulating agents (ESA). 2019. EHA Library. Platzbecker U. 06/12/20; 295003; S183.

54. Steensma DP, Fenaux P, Van Eygen K, Raza A, Santini V, Germing U, Font P, Diez-Campelo M, Thepot S, Vellenga E, et al. Imetelstat achieves meaningful and durable transfusion independence in high transfusion-burden patients with lower-risk myelodysplastic syndromes in a Phase II Study. J Clin Oncol. 2021; 39(1):48-56. doi: 10.1200/JCO.20.01895

55. Malouf R, Ashraf A, Hadjinicolaou AV, Doree C, Hopewell S, Estcourt LJ. In people with bone marrow disorders, a comparison of giving platelet transfusions only when bleeding occurs to also giving them to prevent bleeding. Cochrane Database Syst Rev 2018 May 14; issue 5, art. CD012342.

56. Kantarjian H, Fenaux P, Sekeres MA, Becker PS, Boruchov A, Bowen D, Hellstrom-Lindberg E, Larson RA, Lyons RM, Muus P, Shammo J, et al. Safety and efficacy of romiplostim in patients with lower-risk myelodysplastic syndrome and thrombocytopenia. J Clin Oncol. 2010; 28(3):437-444. doi: 10.1200/JCO.2009.24.7999

57. Giagounidis A, Mufti GJ, Fenaux P, Sekeres MA, Szer J, Platzbecker U, Kuendgen A, Gaidano G, Wiktor-Jedrzejczak W, Hu K, et al. Results of a randomized, double-blind study of romiplostim versus placebo in patients with low/intermediate-1-risk myelodysplastic syndrome and thrombocytopenia. Cancer. 2014; 120(12): 1838-1846. doi: 10.1002/ cncr.28663

58. Kantarjian HM, Fenaux P, Sekeres MA, Szer J, Platzbecker U, Kuendgen A, Gaidano G, Wiktor-Jedrzejczak W, Carpenter N, Mehta B, et al. Long-term follow-up for up to 5 years on the risk of leukaemic progression in thrombocytopenic patients with lower-risk myelodysplastic syndromes treated with romiplostim or placebo in a randomised double-blind trial. Lancet Haematol. 2018; 5(3):e117-e126. doi: $10.1016 /$ S2352-3026(18)30016-4

59. Mittelman M. Good news for patients with myelodysplastic syndromes and thrombocytopenia. Lancet Haematol. 2018 Mar;5(3):e100-101. doi: 10.1016/S2352-3026(18)30017-6

60. Oliva EN, Alati C, Santini V, Poloni A, Molteni A, Niscola P, Salvi F, Sanpaolo G, Balleari E, Germing U, et al. Eltrombopag versus placebo for low-risk myelodysplastic syndromes with thrombocytopenia (EQoL-MDS): phase 1 results of a single-blind, randomised, controlled, phase 2 superiority trial. Lancet Haematol. 2017;4(3):e127-e136. doi: 10.1016/S2352-3026(17)30012-1

61. Mittelman M, Platzbecker U, Afanasyev B, Grosicki S, Wong R, Anagnostopoulos A, Brenner B, et al. Eltrombopag for advanced myelodysplastic syndromes or acute myeloid leukaemia and severe thrombocytopenia (ASPIRE): A randomised, placebo-controlled, phase 2 trial. Lancet Haematology. 2018; 5(1); e34-e43. abstr 3822. doi: 10.1016/S23523026(17)30228-4

62. Dickinson M, Cherif H, Fenaux P, Mittelman M, Verma A, Portella MSO, Burgess P, Ramos PM, Choi J, Platzbecker $U$, et al. Azacitidine with or without eltrombopag for first-line treatment of intermediate- or high-risk MDS with thrombocytopenia. Blood. 2018;132(25):2629-2638. doi: 10.1182/blood-2018-06-855221

63. Mittelman M, Oster HS. Thrombocytopenia in myelodysplastic syndromes: time to lift the embargo on thrombomimetics? Br J Haematol 2021;194(2):231-233. doi: 10.1111/ bjh.17538

64. Mittelman M, Oster HS. Immunosuppressive therapy in myelodysplastic syndromes is still alive. Acta Haematol2015; 134:135-137. doi: $10.1159 / 000371833$

65. Stahl M, DeVeaux M, de Witte T, Neukirchen J, Sekeres MA, Brunner AM, Roboz GJ, Steensma DP, Bhatt VR, Platzbecker $U$, et al. The use of immunosuppressive therapy in MDS: clinical outcomes and their predictors in a large international patient cohort. Blood Adv. 2018; 2(14):1765-1772. doi: 10.1182/bloodadvances.2018019414

66. Hoeks M, Yu G, Langemeijer S, Crouch S, de Swart L, Fenaux P, Symeonidis A, Čermák J, Hellström-Lindberg E, Sanz G, et al. Impact of treatment with iron chelation therapy in patients with lower-risk myelodysplastic syndromes participating in the European MDS registry. Haematologica. 2020;105(3): 640-651. doi: 10.3324/haematol.2018.212332

67. Angelucci E, Li J, Greenberg P, Wu D, Hou M, Montano Figueroa EH, Rodriguez MG, Dong X, Ghosh J, Izquierdo M, Garcia-Manero G; TELESTO study investigators. iron chelation in transfusion-dependent patients with low- to intermediate-1-risk myelodysplastic syndromes: A randomized trial. Ann Intern Med. 2020;172(8):513-522. doi: 10.7326/M19-0916

68. Mittelman M, Lugassy G, Merkel D, Tamary H, Sarid N, Rachmilewitz E, Hershko C; MDS Israel Group; Israel Society of Hematology. Iron chelation therapy in patients with myelodysplastic syndromes: consensus conference guidelines. Isr Med Assoc J. 2008;10: 374-376. PMID:18605364 


\section{Миелодиспластический синдром (МДС) низкой степени риска: подходы к терапии без трансплантации}

\section{Моше Миттельман}

Медицинский центр Сураски, Университ Тель-Авива, Тель-Авив, Израиль

\section{Резюме}

За последние десятилетия достигнут значительный прогресс в понимании биологии и лечении миелодиспластических синдромов (МДС). На основе нескольких клинико-лабораторных параметров (процент бластных клеток, цитогенетические данные, число нарушенных ростков кроветворения) таких пациентов классифицируют по степени риска заболевания (сниженный или высокий риск). Здесь мы обратим особое внимание на МДС низкого риска (НР-МДС). Пациентов с НР-МДС лечат посредством трансфузий эритроцитов (при необходимости), с применением эритропоэз-стимулирующих препаратов или без них. Луспатерсепт, активирующий аналог, является рациональным препаратом для второй линии терапии. Среди изучаемых препаратов в этой области можно упомянуть руксодустат (ингибитор фактора, идуцируемого гипоксией) и иметелстат ингибитор геломеразы. Лечение тромбоцитопении остается проблемным и открытым вопросом.

\section{Ключевые слова}

Миелодиспластический синдром, низкая степень риска, диагностика, лечение, таргетная терапия. 